\title{
A PROSPECTIVE STUDY ON AEROMONAS IN OUTPATIENTS WITH DIARRHEA IN THE CENTRAL REGION OF RIO GRANDE DO SUL STATE
}

Karoline de Campos Prediger ${ }^{1}$, Renata da Silva Pereira ${ }^{2}$, Carlos Hugo Del Priore Winckler Neto ${ }^{2}$, Roberto Christ Vianna Santos ${ }^{1}$, Cyntia Maria Telles Fadel-Picheth ${ }^{3}$, Bruno Stefanello Vizzotto ${ }^{1 *}$

${ }^{1}$ Laboratório de Microbiologia Clínica, Centro Universitário Franciscano, Santa Maria, RS, Brasil; ${ }^{2}$ Laboratório Oswaldo Cruz, Santa Maria, RS, Brasil; ${ }^{3}$ Departamento de Patologia Médica, Universidade Federal do Paraná, Curitiba, PR, Brasil.

Submitted: August 11, 2011; Approved: June 07, 2012.

\begin{abstract}
Aeromonas spp. were identified in five $(2,7 \%)$ of 182 diarrheal stool cultures, A. caviae was predominant, resistant mainly to ampicillin and cephalotin. This is the first study showing the presence of Aeromonas spp. in diarrheal stools of outpatients in the central region of Rio Grande do Sul State, Brazil.
\end{abstract}

Key words: Aeromonas; stools; outpatients; multi-resistance.

The diarrheal disease of infectious origin is considered a great epidemic, being registered 1.8 to 2.5 million deaths annually, representing $20 \%$ of all deaths among children in developing countries (9). Several microorganisms may be responsible for these infections, Aeromonas spp. is one of the notorious causative agent of diarrhea, as well as extraintestinal infections such as cellulitis, wound infections, sepsis, urinary tract infections, among others $(6,13,14,17,18)$. The gastroenteritis caused by Aeromonas spp. vary from acute watery diarrhea, dysentery-like and bloody to chronic diarrhea, affecting mainly children and elderly, being the severity of the disease directly related to virulence factors of the strain and the immune status of the patient $(4,5,18)$. Belonging to the family Aeromonadacea, Aeromonas spp. are widely distributed in nature, especially in aquatic environment (9), and are transmitted to humans mainly by water and food contaminated with the bacteria. In Brazil there are few studies on Aeromonas frequency in diarrheal diseases $(6,7,11,14,15)$, and the bacteria is not searched in the routine of most of clinical laboratories.

The present study aimed to detect the presence of Aeromonas spp. in stools of outpatients with diarrhea attended by clinical laboratories in Santa Maria/RS, motivated by low number of studies regarding this pathogen in the region. Were analyzed 182 diarrheal stool samples collected in the period of June/2010 to May/2011. The samples were inoculated in Alkaline Peptone Water (Himedia, Mumbai, India) and incubated for 24 hours at $25^{\circ} \mathrm{C}$. Then, an aliquot of the culture was inoculated in Nutrient Agar (Himedia, Mumbai, India) and incubated for 24 hours at $37^{\circ} \mathrm{C}$. Four isolated colonies of each culture were analyzed by Gram staining and cytochrome oxidase test (Laborclin, Porto Alegre, RS, Brazil) (15). Suspect colonies, i.e. gram-negative bacilli cytochrome oxidase positive, were tested for reactions used for Aeromonas spp.

\footnotetext{
*Corresponding Author. Mailing address: Laboratório de Microbiologia Clínica, Centro Universitário Franciscano - UNIFRA, Santa Maria, RS, Brasil..; E-
} mail: bvizzotto@yahoo.com.br 
identification: production of catalase, arginine dihidrolase, lysine and ornithine decarboxylase, citrate, production of gas from glucose, fermentation of D-adonitol, L-arabinose, Ldextrose, L-dulcitol, m-inositol, lactose, D-mannitol, mannose, raffinose, L-rhamnose, D-sorbitol, sucrose and D-trehalose, production of indole, motility, Voges-Proskauer and aesculin hydrolysis (1). The antimicrobial susceptibility test was realized by disk diffusion method (3), with the following antimicrobials (Laborclin, Porto Alegre, RS, Brazil): nalidixic acid $(30 \mu \mathrm{g})$, amoxacillin/clavulanic acid (20/10 $\mu \mathrm{g})$, ampicillin $(10 \mu \mathrm{g})$, amikacin $(30 \mu \mathrm{g})$, aztreonam $(30 \mu \mathrm{g})$, cephalothin (30 $\mu \mathrm{g}$,), cefazolin $(30 \mu \mathrm{g})$, cefepime $(30 \mu \mathrm{g})$, cefotaxime $(30 \mu \mathrm{g})$, cefoxitin $(30 \mu \mathrm{g})$, ceftazidime $(30 \mu \mathrm{g})$, ceftriaxone $(30 \mu \mathrm{g})$, ciprofloxacin $(5 \mu \mathrm{g})$, chloranphenicol $(30 \mu \mathrm{g})$, gentamicin $(10$ $\mu \mathrm{g})$, imipenem $(10 \mu \mathrm{g})$, trimethoprim-sulfamethoxazole (25 $\mu \mathrm{g})$, tobramycin $(10 \mu \mathrm{g})$ and tetracycline $(30 \mu \mathrm{g})$. This study was approved by the Ethics Committee of our University (CEP/UNIFRA) under registration no. 043.2011.2.

The presence of Aeromonas spp. was confirmed in 2.7\% $(5 / 182)$ of the samples, with the predominance of $A$. caviae (4/5), followed by $A$. hydrophila (1/5) (Table 1). The prevalence was similar to that related by Surek et al. (15) who found $2.6 \%$ of Aeromonas spp. among people with diarrhea in Paraná State, also in Southern Brazil, and other studies made in different regions of the country; in all of them $A$. caviae was also the most prevalent species $(7,11,14)$. However our data are in disagreement with those described by Guerra et al. (6) which found a frequency of 6.6\% of Aeromonas spp. in Rio Grande do Sul State and A. hydrophila as the most prevalent species. These differences may be due to the kind of sample studied: while ours included only outpatients, those analyzed by Guerra et al. (6) was composed by inpatients, what also may explain the predominance of $A$. hydrophila. Regarding the antimicrobial susceptibility test, all strains showed resistance to ampicillin and cephalothin, what is in agreement with the fact that species of Aeromonas are intrinsically resistant to ampicillin (with the exception of $A$. trota) and cephalothin (with the exception of $A$. veronii biovar sobria) $(1,6)$. Among the other antimicrobials tested, resistance to amoxicillin/clavulanic acid was the most common, followed by cefazolin. In total resistance was found to 9 of the 19 antimicrobials tested. Three strains (LOC-02, LOC-81 and LP1) were multi-resistant (Table 1). These data together suggests that the resistance of Aeromonas should be monitorated.

This study demonstrated, in a pioneer way, the prevalence of Aeromonas spp. in stools of outpatients with diarrhea in the central region of Rio Grande do Sul State, Brazil. The frequency found is similar to those related for some other enteric pathogens $(2,10,12,16)$ emphasizing the importance of its research by clinical laboratories in the region.

Table 1. Characterization of Aeromonas spp. isolated from stool samples of outpatients.

\begin{tabular}{|c|c|c|c|}
\hline Samples & Age $^{1}$ & Species $^{2}$ & Susceptibility Profile $^{3}$ \\
\hline LOC-02 & $6 \mathrm{~m}$ & A. caviae & $\mathrm{AMP}^{\mathrm{R}} ; \mathrm{CFL}^{\mathrm{R}} ; \mathrm{CFZ}^{\mathrm{R}} ; \mathrm{CFO}^{\mathrm{I}} ; \mathrm{CLO}^{\mathrm{R}}$ \\
\hline LOC-81 & NI & A. hydrophila & $\mathrm{AMP}^{\mathrm{R}} ; \mathrm{CFL}^{\mathrm{R}} ; \mathrm{CFZ}^{\mathrm{I}} ; \mathrm{AMC}^{\mathrm{R}} ; \mathrm{AZT}^{\mathrm{I}}$ \\
\hline LOC-121 & $70 y$ & A. caviae & $\mathrm{AMP}^{\mathrm{R}} ; \mathrm{CFL}^{\mathrm{R}} ; \mathrm{AMC}^{\mathrm{R}}$ \\
\hline LP-1 & NI & A. caviae & $\mathrm{AMP}^{\mathrm{R}} ; \mathrm{CFL}^{\mathrm{R}} ; \mathrm{CFZ}^{\mathrm{R}} ; \mathrm{AMC}^{\mathrm{R}} ; \mathrm{TET}^{\mathrm{I}} ; \mathrm{SXT}^{\mathrm{R}}$ \\
\hline LP-15 & NI & A. caviae & $\mathrm{AMP}^{\mathrm{R}} ; \mathrm{CFL}^{\mathrm{R}} ; \mathrm{TET}^{\mathrm{R}}$ \\
\hline
\end{tabular}

\section{REFERENCES}

1. Abbott, S.L.; Cheung, W.K.W.; Janda, J.M. (2003). The genus
Aeromonas: biochemical characteristics, atypical reactions, and phenotypic identification schemes. J Clin Microbiol. 41 (6), 2348-2357.

2. Albuquerque, M. C. M.; Rocha, L. N.; Benati, F. J.; Soares, C. C.; 
Maranhão, A. G.; Ramírez, M. L.; Erdman, D.; Santos, N. (2007). Human bocavirus infection in children with gastroenteritis, Brazil. Emerg. Infect. Dis. 13 (11), 1756-1758.

3. Clinical and Laboratorial Standards Institute (CLSI) (2006). Methods for antimicrobial dilution and disk susceptibility testing of infrequently isolated or fastidious bacteria. Proposed guideline. M45-A, 26 (19), 1213.

4. Dwivedi, M.; Mishra, A.; Prasad, A.; Azim, A.; Singh, R.K.; Baronia, A.K.; Prasad, K.N.; Dwivedi, U.N. (2008). Aeromonas caviae septicemia in immunocompetent gastrointestinal carriers. Braz. J. infect. Dis. 12 (6), 547-548.

5. Ghenghesh, K.S.; Ahmed, S.; El-Khalek, R.A.; Al-Gendy, A.; Klena, J. (2008). Aeromonas-Associated infections in developing countries. $J$ Infect Developing Countries. 2 (2), 81-98.

6. Guerra, I.M.F.; Fadanelli, R.; Figueiró, M.; Schreiner, F.; Delamare, A.P.L.; Wollheim, C.; Costa, S.O.P.; Echeverrigaray, S. (2007) Aeromonas associated diarrhoeal disease in south Brazil: prevalence, virulence factores and antimicrobial resistance. Braz. J. Microbiol. (38), 638-643.

7. Hofer, E.; Reis, C.M.F.; Theophilo, G.N.D.; Cavalcanti, V.O.; Lima, N.V., Henriques, M.F.C.M. (2006). Envolvimento de Aeromonas em surto de doença diarréica aguda em São Bento do Una, Pernambuco. Rev. Soc. Bras. Med. Trop. 39 (2), 217-220.

8. Janda, J.M.; Abbott, S. L. (2010). The genus Aeromonas: taxonomy, pathogenicity, and infection. Clin. Microbiol. Rev. 23 (1), 35-73.

9. Janda, J. M.; Abbott, S. L. (2011). Revisiting bacterial gastroenteritis, Part I: Issues, possible approaches, and an ever-expanding list of etiologic agents. Clin. Microbiol. Newsletter. 33 (10), 71-76.

10. Loureiro, E. C. B.; Souza, C. O.; Sousa, E. B.; Santos, D. V.; Rocha, D. C. C.; Ramos, F. L. P.; Silva, M. C. M. (2010). Detecção de bactérias enteropatogênicas e enteroparasitas em pacientes com diarréia aguda em
Juruti, Pará, Brasil. Rev.Pan-Amaz. Saude. 1 (1), 143-148.

11. Nojimoto, I.T.I.; Bezana, C.S.C.; Do Carmo, 0043.; Valadão, L.M., Carrijo, K.M. (1997) - Prevalência de Aeromonas spp. em fezes diarréicas de crianças menores de 5 anos de idade na cidade de Goiânia, Goiás, no biênio 1995-1997. Rev. Soc. Bras. Med. Trop. 30 (5), 385-388.

12. Orlandi, P. P.; Magalhães, G. F.; Matos, N. B.; Silva, T.; Penatti, M.; Nogueira, P. A.; Pereira da Silva, L. H. (2006). Etiology of diarrheal infections in children of Porto Velho (Rondonia, Western Amazon region, Brazil). Braz. J. Med. Biol. Res. 39 (4), 507-517.

13. Parker, J.L.; Shaw, J.G. (2011). Aeromonas spp. clinical microbiology and disease. J. Infect. 62 (2), 109-118.

14. Pereira, C.S.; Amorim, S.D.; Santos, A.F.M.; Reis, C.M.F.; Theophilo, G.N.D.; Rodrigues, D.P. (2008). Caracterização de Aeromonas spp. isoladas de neonatos hospitalizados. Rev. Soc. Bras. Med. Trop. 41 (2), 179-182.

15. Surek, M.; Vizzotto, B.S.; Souza, E.M.; Pedrosa, F.O.; Dallagassa, C.B.; Farah, S.M.S.S.; Fadel-Picheth, C. M. T. (2010). Identification and antimicrobial susceptibility of Aeromonas spp. isolated from stool samples of Brazilian subjects with diarrhoea and healthy controls. $J$. Med. Microbiol. 59, 373-374.

16. Toni, F.; De Souza, E. M.; Pedrosa, F. O.; Klassen, G.; Irino, K.; Un Rigo, L.; Steffens, M. B. R.; Fialho, O. B.; Farah, S. M. S. S.; FadelPicheth, C. M. T. (2009). A prospective study on Shiga toxin-producing Escherichia coli in children with diarrhoea in Paraná State, Brazil. Lett. Appl. Microbiol. 48 (5), 645-647.

17. Vila, J.; Ruiz, J.; Gallardo, J.; Vargas, M.; Soler, L.; Figueras, M.J.; Gascón, J. (2003). Aeromonas spp. and traveler's diarrhoea: clinical features and antimicrobial resistance. Emerg. Infect. Dis.. 9 (5), 552-555.

18. von Graevenitz, A. (2007). The role of Aeromonas in diarrhea: a review. Infection. 35 (2), 59-64. 